\title{
Pedagogiczny wymiar polskiej ludowej teologii i pobożności według Edmunda Bojanowskiego. Szkic do badań pedagogiczno-etnologiczno-religijnych
}

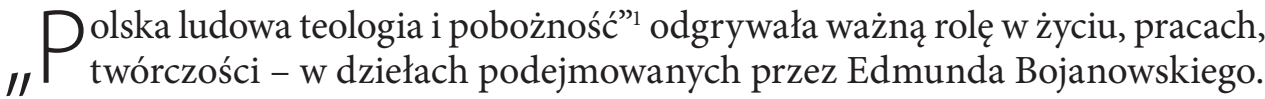
Ludowa teologia nie jest wszakże wymieniana ani omawiana w podręcznikach z zakresu metodologii teologicznej. Nie ma ona w sensie ścisłym wymiaru naukowego. Trudno wskazać, np. w ludowej teologii metody badawcze. Przedmiot natomiast oraz jej zadania są widoczne bardzo wyraźnie. Ludową pobożnością z kolei zainteresowana jest etnologia. W pedagogicznej teorii oraz pragmatyce Edmunda Bojanowskiego obecne były wątki ludowej teologii i pobożności.

O kształcie polskiej obrzędowości religijnej, w czasach kiedy żył E. Bojanowski (ale też i w każdym innym czasie) stanowił zmysł wiary ludu Bożego - sensus fidei. Teologia jako nauka „o Bogu i człowieku w Chrystusie” (ks. W. Granat) miała ludowy, narodowy, etniczny, pedagogiczny wymiar. „Polska ludowa teologia i pobożność” była u E. Bojanowskiego w gruncie rzeczy pedagogią.

\footnotetext{
* Prof. DR hab. Eugeniusz SAKowiCz - teolog, religioznawca, encyklopedysta-leksykograf; profesor nauk teologicznych (od 2007 r.); profesor zwyczajny, kierownik Katedry Religiologii i Dialogu Międzyreligijnego w Instytucie Dialogu Kultury i Religii na Wydziale Teologicznym UKSW w Warszawie; członek Komitetu Nauk Teologicznych Polskiej Akademii Nauk. E-mail: eugeniusz.sakowicz@wp.pl.

${ }^{1}$ Godny uwagi jest temat „Religijność ludowa”, zrealizowany w piśmie „Communio. Międzynarodowy Przegląd Teologiczny” 7(1987), nr 6. Zob. też blok tematyczny, opracowany pod red. E. Sakowicza pt. „Ludowa teologia i pobożność” - cz. I., Ateneum Kapłańskie” 155(2010), z. 1; cz. II, Ateneum Kapłańskie” 155(2010), z. 2. Zob. nadto rozdział III pt. „Zwyczaje, wierzenia i obrzędy religijne w przeszłości i dobie współczesnej" (na który składa się 10 opracowań) w: Z. Kupisiński (red.), Potrzeba religii. Dynamika praktyk religijnych i rytualnych, Lublin 2015.
} 


\section{Oryginalność i specyfika ludowej teologii i pobożności}

U początku refleksji E. Bojanowskiego o Bogu, postaciach świętych, dniach uroczystych i świątecznych był kerygmat, nauka głoszona przez kapłanów, duszpasterzy, których on znał i „słuchał” od dzieciństwa. Podwaliny wiary chrześcijańskiej w Polsce kładli misjonarze, niestrudzeni ewangelizatorzy ludu zamieszkującego tu od wieków.

Ludowa teologia nie była formowana na fakultetach teologicznych. Rodziła się, kształtowała w miejscach, w których „odwiecznie” znajdowały się najważniejsze „katedry” wiary i moralności chrześcijańskiej. Były to nędzne wiejskie chaty, usytuowane w zapadłych przysiółkach czy chutorach, ale równocześnie dworki ludzi zamożnych, „promieniujące” na wieśniacze okolice. Teologia ludowa krzepła zarówno wśród ludzi ubogich, jak i zamożnych - bogatych. Zresztą słowa te - ubodzy i bogaci - określające nie tylko stan majątkowy, posiadają teoforyczną wymowę. „Kryje się” w tych słowach Bóg².

Mimo pewnych "rysów” nieortodoksyjnych, ludowa teologia i pobożność pozostawała prawowierną. Było to wielką troską E. Bojanowskiego. Znał on tzw. zabobony, stanowiące poważne zagrożenie dla czystości wiary. Opisując i analizując historię w ogóle czy historię naturalną, w szczególności zwracał uwagę na "dzieje bajeczne”. Podejmował trud odwodzenia prostego ludu od zabobonów. W tym celu uwrażliwił Siostry służebniczki na cel ich posługi, ich pedagogicznej pracy, którym miało być wzmacnianie wiary w Boga, nauczanie prawd chrześcijańskich z jednej strony, a poznawanie kultury, zachowanie tradycji i skarbów polskich pamiątek $\mathrm{z}$ drugiej3

E. Bojanowski pisał: „Zaiste ważnym jest to już co do dzieci, a tym potrzebniejsze, aby Służebnice Ochron, czyniąc nowe w domowym gospodarstwie doświadczenia i próbując rolniczych sposobów, szerzyły między ludem ich używanie, oraz wytępiały przesądy gospodarcze - lub też sprawdzały te, które są godne zachowania i wyjaśnienia a uchodzą za zabobony, np. - obwiązywanie drzew słomą, rzucanie żelaza do mleka, aby się śmietana ustawała".

Nasz pedagog opisywał różne zabobony i inne błędne przekonania motywujące określone działania po to, by odwrócić ludność wiejską od magii, ale też by nauczyć ją właściwych sposobów gospodarowania. Nie mogło ono czerpać motywacji z fikcji, a tę przecież stanowiły zabobony. Pragnieniem bł. Edmunda Bojanowskiego było budowanie harmonijnej rzeczywistości, wyznaczanej przez:

2 Zob. J. Łobodziński, Bogactwo ludowej teologii i pobożności, „Ateneum Kapłańskie” 155(2010) z. 1, s. 7-12.

${ }^{3}$ Zob. E. Gigilewicz, M.L. Opiela (red.), Prace, szkice i notatki Edmunda Bojanowskiego. Inedita, t. 2, Lublin 2016, s. 48, 58-59, 170, 202.

${ }^{4}$ E. Gigilewicz, M.L. Opiela (red.), Prace, szkice i notatki Edmunda Bojanowskiego. Inedita, t. 1, Lublin 2016, s. 588. 
naturę - religię - historię. W niej - podkreślał - przebiega życie człowieka. Rzeczywistość ta w gruncie rzeczy „opisywała” człowieka, jego kulturę, na której sposób on żył. Właśnie dlatego należało ją badać, analizować.

Ludowa teologia charakteryzowała się prostotą. $Z$ domów, w których była uprawiana dziecięca - ufna ludowa teologia wychodzili przyszli teologowie akademiccy, prezbiterzy dostojni, szanujący innych i siebie, o szerokich horyzontach myśli i nade wszystko jej głębi. Wiejskie chaty, ozdobione - niczym świątynie - licznymi „świętymi obrazami” pozostawały przez wieki przybytkami wiary i tradycji. Ludowa teologia, ale też i wiara ludu Bożego była zawsze „miejscem teologicznym” (loci theolgici). Wiedział to E. Bojanowski, chociaż nie znał tego określenia.

Pobożność ludowa wyrażała się w tradycyjnych nabożeństwach, nasyconych wyjątkowo bogatą symboliką. Zawsze odsyłała ona do „czegoś innego”, do tego, co głębsze, ale i wyższe. Obrzędowość ludowa, która jest motywem pobożności „ludu” żyła symbolami. Każde święto czy uroczystość celebrowana, przeżywana, doświadczana, praktykowana, adorowana stanowiła wyjątkowo bogaty „symboliczny" zapis. Powszechne w ludowej pobożności były litanie odmawiane ku czci Pana Jezusa, Matki Najświętszej i świętych, odmawiane publicznie, bądź prywatnie . $^{5}$

Ludzie prości, praktykujący religię, czyli właśnie żyjący pobożnością ludową - zarówno na co dzień, jak i w święta, potrafili odczytywać sens symboli. Wiedzieli jaka jest wymowa dwunastu potraw na stole wigilijnym i dla kogo należy puste miejsce przy stole. Znali na pamięć nie tylko jedną, czy dwie zwrotki tradycyjnej kolędy, ale niemal wszystkie jej strofy. Wiedzieli, że owies pobłogosławiony przez kapłana w Drugi Dzień Świąt Bożego Narodzenia - Świętego Szczepana oznacza grad kamieni miotanych w pierwszego chrześcijańskiego męczennika przez oprawców, którym patronował Szaweł, późniejszy - po nawróceniu - św. Paweł Apostoł. Ziarna te będą rzucone w glebę, by wydać plon stokrotny. W uroczystość Matki Bożej Siewnej - dzień pamięci wiernych o narodzeniu Najświętszej Maryi Panny przynosili ziarno siewne, by kapłan je pobłogosławił i w ten sposób uchronił przyszłe plony przed suszą, gradem, czy innymi kataklizmami natury ${ }^{6}$.

Ludowa pobożność była dla E. Bojanowskiego dowodem na fakt przekładania wiary, wierzeń - teologii na czyny, działania, postępowanie.

5 Zob. E. Gigilewicz, M.L. Opiela (red.), Prace, szkice i notatki ..., t. 1, s. 839-845.

"Zob. J. Perszon, Pobożność ludowa - zmierzch czy transformacja?, „Ateneum Kapłańskie” 155(2010), z. 2, s. 228-246. 


\section{Patriotyczny „duch" polskiej ludowej teologii i pobożności oraz wychowanie do polskości}

Wierzenia, zwyczaje i obrzędy ludowe miały zawsze w Polsce patriotyczną wymowę. Przekazywane z pokolenia na pokolenie przekonanie, iż „Polak to katolik", na pewno znane było E. Bojanowskiemu, jeśli nie explicite to na pewno implicite.

Chrystus frasobliwy, cierpiący ukazywany w ludowych rzeźbach symbolizował Polskę. Maryja, Matka Boża, której „serce przebił miecz boleści” wskazywała również na Rzeczpospolitą, nie tylko obojga narodów, ale wielu narodów. W kontekście kultury, religii, zwyczajów, wierzeń i obrzędów, nadto języka tych narodów kształtowała się specyfika polskiej ludowej teologii i pobożności. Pobożne rzeźby i obrazy podtrzymywały u Polaków cnotę pietyzmu, wierności do ojczyzny, tej wymazanej z map, ale nigdy nie wymazanej z serc Polaków i tej poddawanej ubezwłasnowolnieniu, ale nigdy - nawet w niewoli - nie zniewolonej.

Najbardziej polskimi z polskich wierzeniami, zwyczajami i obrzędami były zawsze te związane z Wigilią Bożego Narodzenia7. Wigilia, zaczynająca się z chwilą wypatrzenia na niebie pierwszej gwiazdki i modlitwą, a następnie łamaniem opłatkiem jest „szczytem” polskości. W chwili wyjątkowej, która zaczynała wieczerzę wielopokoleniową, rodzina, osoby bliskie, przyjaciele, kiedyś również służba przełamywali się solidarnie opłatkiem, wypowiadając słowa przebaczenia, życzliwości, zgody, chociażby jak: „Dzielmy się chlebem anielskim, byśmy spotkali się w Królestwie Niebieskim". W wigilijny wieczór modlono się za zmarłych, zapraszanych do stołu, by zajmowali puste miejsce, zostawiane również dla nich, a nie tylko dla wędrowca, przybysza. W wieczór wigilijny ujawniała się nadto jedność wszelkiego stworzenia - ludzi i zwierząt. Jezus Chrystus narodził się bowiem - jak głosiła przez wieki polska ludowa teologia i pobożność - w „ubogiej, cichej, stajence lichej”. To z naszymi „braćmi i siostrami” - zwierzętami (tak mówił św. Franciszek z Asyżu, którego duchowi synowie i córki upowszechnili na polskiej ziemi żłóbki i jasełka) łamano się przez wieki kolorowym opłatkiem ${ }^{8}$.

Zmartwychwstanie Pana Jezusa - Wielkanoc, szczególnie w czasie, kiedy w Polsce, czy na jej ziemiach „szalała” kultura uśmiercania ducha polskości, zawsze było znakiem nadziei na odrodzenie narodu, państwa. Znajdowało to wyraz w dekoracjach świątecznych, w modlitwach odnoszonych do realiów życia czasie zaborów.

Ludowe świątki, niezliczone krzyże przydrożne, kapliczki, niezliczone wprost rzeźby ukazujące św. Jana Nepomucena (żyjącego w XIV w.), usytuowane

\footnotetext{
7 Zob. E. Gigilewicz, M.L. Opiela (red.), Prace, szkice i notatki ..., t. 1, s. 292-300; t. 2, s. 319-320.

8 Zob. tamże, t. 2. s. 301-303.
} 
w wioskach i osadach, ale też miastach i miasteczkach, a nawet na polach symbolizowały Bożą opiekę nad wiernymi Kościoła, chodzącymi różnymi drogami, przechodzącymi przez różne mosty i kładki. Polskie świątki przydrożne i rozdrożne (stojące na rozdrożach) troszczyły się o tych nawet, co zeszli na bezdroża.

Największym skarbem polskiej ludowej teologii i pobożności zawsze była rodzina. Wiedział to E. Bojanowski i dlatego służąc dzieciom, chciał jej służyć. To rodzina pielęgnowała wiarę swoich dzieci i wnuków. Strzegła skarbów tej wiary, tradycji, szacunku dla Boga, przywiązania do ojczyzny. Respektowała honor jako cnotę „bardzo polską”. Uczyła wstydu jako wartości wyjątkowej w rzeczywistości, tych narodów, w tym polskiego, które poczuwały się do dziedzictwa Chrystusowego i ewangelicznego.

„Wychowywanie do polskości” realizowane było przez E. Bojanowskiego na drodze uwrażliwiania młodego pokolenia (ale i starszej generacji również) na własną historię. Błogosławiony pedagog prowadził „lekcje” szacunku do przeszłości, do przodków, do dziedzictwa narodowego i kulturowego dorobku Polaków. Przekonywał, iż „korzeniom” własnej kultury należny jest szacunek 9 . Czerpią one ożywcze soki z dziejowego podglebia dla przyszłości, dla pokoleń, które nadejdą. W wychowaniu tym ważny był wierny przekaz prawd historycznych, co miało gwarantować „jasną" przyszłość tych, którzy znają i cenią własną tożsamość, którzy wiedzą, kim są i kim chcą być i będą. Historia była pasją E. Bojanowskiego. „Wychowywanie do polskości” było uczeniem się „przywiązania” do pamięci historycznej. Miało ono na celu respekt do samego siebie jako Polaka. Ważną przestrzeń „wychowania do polskości” wyznaczała wg E. Bojanowskiego religia. Przez wieki była ona motywem polskości. Służyła jej, kształtowała jej ducha. Zrosła się niemal organicznie z narodem ${ }^{10}$.

Wielkim „obszarem” czy „polem” pracy na rzecz polskości zawsze była kultura słowa, w tym „zapisanego” (w literaturze pięknej). Wychowanie do polskości oznaczało żywienie szacunku dla polskiej literatury pięknej, do wieszczów narodowych, którzy jak „prorocy” postrzegali rzeczywistość Polski, jej przyszłość, ale i dramatyczną teraźniejszość. E. Bojanowski przywoływał treści dzieł literackich, by one ożywiały ducha narodowego.

Wychowanie do polskości przebiegało w czasach E. Bojanowskiego w określonym kontekście dziejowym. Było to nieustanne zmaganie się o przetrwanie polskości, o wierność temu, co polskie. W procesie pedagogii polskości konieczny był patronat wybitnych nauczycieli duchowych. Byli nimi wg bł. E. Bojanowskiego: św. bp. Stanisław (Szczepanowski), św. Jadwiga, ks. Piotr Skarga, Jan Kochanowski, Jan III Sobieski, Tadeusz Kościuszko.

\footnotetext{
9 Zob. E. Gigilewicz, M.L. Opiela (red,), Prace, szkice i notatki ..., t. 2, s. 31-32.

${ }^{10}$ Zob. tamże, s. 27-99.
} 
Znał E. Bojanowski polskie wady. Nie były to inne wady od tych „występujących” i w innych epokach (a także w dobie współczesnej), takich jak: pycha, buta, zazdrość, niemoralność (szczególnie w sferze obyczajowości), „słomiany zapał”, podatność na manipulację ze strony (rzekomo) silniejszego (bo posiadającego aktualnie władzę), czołobitność przed władcami życia politycznego (w tym przed ludźmi z gruntu nieuczciwymi i zdeprawowanymi), lekceważenie autorytetów, brak troski o dobro wspólne, niegospodarność i zamiłowanie do bałaganu, bohaterstwo na wojnie, a tchórzostwo w dniach powszednich, podatność na euforię w uroczystości i święta, a apatia w dni szare i monotonne, uwielbianie pochodów, procesji, przemarszu, pielgrzymek, a uciekanie przed trudem dawania świadectwa prawdzie „w ukryciu”, bez rozgłosu, w zaciszu domu rodzinnego ${ }^{11}$.

Wychowanie do polskości polegało na takim prowadzeniu młodego, a także dojrzałego pokolenia Polek i Polaków, by czuło ono silne więzi z całym narodem polskim i rozumiało ich sens. Nie mogły to być więzi zewnętrzne - takie są tylko więzami, krepującymi wolność, pierwszą cechę polskości. Motywowane od wewnątrz uczynią człowieka - będącego w relacji do drugiego i drugich wolnym i szanującym wolności innych.

„Wychowanie patriotyczne - pisze Lidia Marszałek w dziele Duchowość dziecka. Znacznie, perspektyw, konteksty w pedagogice przedszkolnej - Bojanowski rozumiał jako «pielęgnowanie ducha patriotyzmu w ludzie, ochronę wartości narodowych poprzez zachowanie tradycji i zwyczajów, znajomość literatury, języka, i historii Polski, pamięć o rocznicach». W tym zakresie stawiał zadanie ochrony dziedzictwa kulturowego, kultywowania i wykorzystania jego dynamicznej i rozwijającej siły, dostrzegając analogie między prawidłami życia i rozwoju ludzkości, poszczególnych narodów oraz pojedynczego człowieka"12.

Edukacja - jak uważał E. Bojanowski - służyć miała odzyskaniu przez Polskę niepodległości, zachowaniu języka i dziedzictwa kultury, a tym samym tożsamości narodowej. Błogosławiony pedagog zamierzał przygotować dzieło prezentujące system edukacji, w którym ukazałby jego strukturalny i funkcjonalny wymiar. E. Bojanowski poczynił szkice planu książki oraz zgromadził odpowiednie materiały, w tym z zakresu polskiej etnografii, etnologii, etnomuzykologii ${ }^{13}$.

\footnotetext{
11 Zob. tamże, s. 99-108.

${ }_{12}$ L. Marszałek, Duchowość dziecka. Znacznie, perspektyw, konteksty w pedagogice przedszkolnej, Warszawa 2013, s. 369.

${ }^{13}$ S. M.L. Opiela wraz z Zespołem Badawczym i Komisją ds. Wychowania Sióstr Służebniczek BDNP - Sekcja ds. Ochronek zrealizowała ów pedagogiczny plan założyciela zgromadzenia zakonnego i inspiratora ochronek, którego owocem jest dzieło pod jej redakcją pt. Kompendium edukacyjne Edmunda Bojanowskiego, Lublin 2016.
} 


\section{Aspekty wychowawcze wierzeń, obrzędów i zwyczajów ludowych}

Edmund Bojanowski widział, iż człowiek jest nieustannie - od dzieciństwa do starości - wychowywany, przede wszystkim przez swoją rodzinę, najbliższych, ale też i innych ludzi, przez instytucje ku temu celowi powołane oraz przez rozliczne sytuacje i okoliczności życiowe.

Według ks. Józefa Łobodzińskiego: „Godny zaakcentowania jest (...) aspekt wychowawczy zwyczajów i obrzędów ludowych. Publiczne wyśmiewanie aspołecznych postaw, a jednocześnie preferowanie postaw pozytywnych stanowiło duży czynnik wychowawczy"14.

E. Bojanowski podejmował trud zrozumienia pedagogicznego przesłania ludowej teologii i pobożności. Wszystkie zrytualizowane czynności i działania oraz słowa otaczane były pamięcią, zbiorową troską ze względu na ich „przeznaczenie", cel i zadania, funkcje.

Celem sprawowanych rytualnych czynności było przekazywanie mądrości życiowej, odkrytej kiedyś przez protoplastów rodu, przodków rodziny, współmieszkańców tej samej wsi, tzn. „współplemieńców”. Życiowa mądrość nie była „uczonością” wyczytaną z książek. Wypływała z uważnej „lektury” „księgi przyrody", natury.

Źródłem mądrości było umiejętne „odczytywanie”, czyli poznawanie i interpretowanie otaczającego świata: innych ludzi, ale też zwierząt, roślinnej „szaty”, przedmiotów nazywanych „martwymi”, które w rytualnych sceneriach wcale martwymi nie były. Spełnianie obrzędów tradycyjnych uczyło spostrzegawczości, wyrabiało specyficzny zmysł „,analityczny”. Konstruowało swoistą „filozofię życia”.

Praktykowanie obrzędów uczyło ich uczestników „komunii pokoleń”. „Komunia osób” w kontekście wiejskim zawsze szła w parze z „komunią świata ożywionego i nieożywionego". Mieszkańcy wsi i przysiółków zawsze mieli całościowy ogląd świata. Nie zatrzymywali się na swojej „zagrodzie”15.

Mieszkaniec wsi, rolnik, chłop wiedział, kim jest. Wszystko brał na „chłopski rozum”, czyli był realistą, kierował się logiką. Zwyczaje i obrzędy spełniane w określonym rytmie (przy zachowaniu usankcjonowanej tradycją harmonii, porządku wydarzeń) uczyły wszystkich w nich biorących udział szacunku dla własnej tożsamości. Utwierdzały w pewnej „chłopskiej dumie”, która żadną miarą nie była pychą, czy też postawą butności i pogardy wobec innych. Mieszkaniec wsi będąc prostym, nie był „prostakiem”'16.

Spełniane obrzędy przyczyniały się do samoidentyfikacji, wpierw w rodzinie, następnie w kręgu bliższych i dalszych krewnych, wreszcie w wiosce. W środo-

${ }_{14} \mathrm{~J}$. Łobodziński, Bogactwo ludowej teologii i pobożności..., s. 11.

${ }_{15}$ Zob. E. Gigilewicz, M.L. Opiela (red.), Prace, szkice i notatki..., t. 2, s. 17.

${ }_{16}$ Zob. tamże, s. 20-22. 
wisku rodzinnym zaspakajane były najgłębsze potrzeby człowieka, takie jak: przekonanie o sensie życia, aktywny i odpowiedzialny udział we wspólnocie, rozumienia świata, „budowanie siebie”. Obrzędowość ożywiała i wzmacniała więzi rodzinne i wioskowe.

Życie mieszkańców wsi było bardzo zrytualizowane. Spełniający obrzędy, biorący w nich udział nie tylko odkrywali związki między „dziśs" a „wczoraj”, ale też utwierdzali się w przekonaniu, że przyroda związana jest nierozdzielnie z historią. Świadectwem tego były groby, czy to pojedynczych osób walczących o wolność Ojczyzny, czy też zbiorowe mogiły, rozsiane po polach i lasach.

Pamięć o wydarzeniach przeszłych „ujawniała się" w rytualnych przedstawieniach, w trakcie których - oprócz postaci z innego wymiaru życia (świętych, zmarłych, postaci będącej alegorią śmierci, ludzko-zwierzęcych „figur”) pojawiali się żołnierze armii zaborczych (Moskale czy Austriacy), bądź też Żydzi (notabene zawsze obecni w polskim krajobrazie kulturowym).

Oprawa Świąt Bożego Narodzenia, szczególnie wspomnianej Wigilii Bożego Narodzenia miała zawsze silny patriotyczny charakter. Obrzędowość uczyła miłości do Ojczyzny, do ziemi Ojców, tradycji Kościoła katolickiego. Wierność Ojczyźnie szła w parze z wiernością Bogu.

Uczestnictwo w nabożeństwach majowych - majówkach, przy kolorowo przystrojonych kapliczkach, przy drzewach „umajonych” wskazywały na żywy związek wiernych z Kościołem. Odmawiane litanie, zarówno przez dzieci, jak i dorosłych, starców (bez towarzyszącego im kapłana) uczyły przekonania o powszechnej odpowiedzialności za Kościół. Kapliczki wiejskie wyznaczały sakralną przestrzeń, na której uprawiana była ziemia wg „wizji” podanej przez natchnionego autora Księgi Rodzaju. Gospodarz i jego małżonka oraz dzieci (od małości zaprawione w ciężkiej polowej pracy oraz przy spełnianiu obrządku inwentarza) stawali się współpracownikami Boga Stwórcy. Czynili sobie Ziemię poddaną (por. Rdz 1,28). Cenili pracę, wiedzieli, że lenistwo jest wyjątkowym wrogiem człowieka.

Wielką lekcję dawała sztuka ludowa. Umieszczone w szczytach domów figurki, obrazki tworzyły swoistą przestrzeń sakralną. Domy stawały się dzięki tym kapliczkom - „kaplicami”, „świątyniami”, w których szanuje się tradycję, oddaje się cześć rodzicom (całując $\mathrm{w}$ geście pokory spracowane dłonie ojca i matki), ceni się więzi rodzinne, $\mathrm{z}$ respektem odnosi się do starców, raduje się z każdego poczętego i nowonarodzonego życia ${ }^{17}$. Podobnie o poświęceniu domu i zagrody opiece Bożej Opatrzności świadczyły: wypalone na belkach izb krzyże, zawieszone wianuszki, pokropione wodą święcona przez kapłana w Święto Matki Boskiej Zielnej (Wniebowzięcie Najświętszej Maryi Panny),

17 Zob. E. Gigilewicz, M.L. Opiela (red.), Prace, szkice i notatki ..., t. 2, s. 437-441. 
galeria „świętych obrazów”, wyeksponowana w głównej izbie nad małżeńskim łożem oraz w innych miejscach chaty.

Uczestnictwo w obrzędach i zwyczajach zawsze uczyło pokory wobec Wszechmogącego Boga, ale i przyrody, którą On włada i kieruje. Nawałnice, kataklizmy przyrody „odpędzane” były siłą solidarnej, rodzinnej czy też „parafialnej” modlitwy. Wielką moc miały suplikacje, śpiewane w wiejskich kościołach w momentach szczególnej traumy, strapienia i lęku. Bóg zawsze bronił „od powietrza, głodu, ognia i wojny"18.

Współtowarzyszami mieszkańców wsi byli święci bardzo mocno wpisani w kalendarz doroczny. Nie byli oni obcymi dla żyjących na wsiach. Stanowili swoistą grupę obywateli wiosek, poczynając od Apostołów, poprzez postacie z „Litanii do Wszystkich Świętych”, patronów prac polowych, czuwających nad zdrowiem ludzi i zwierząt, nad plennością roślin i pogodą, troszczących się o ziarna (jak wspomniany wyżej święty diakon Szczepan, ukamienowany na kartach Biblii, a w obrzędowości agrarnej troszczący się o ziarna, mające wskazywać na kamienie, które Bóg zamienić może w zarodki życia).

Praktykujący zwyczaje i obrzędy potrafili odczytywać „czas” i jego „znaki”. Znali jego „wyzwania”. Żyli zgodnie z jego harmonią, jego mądrym rytmem. Szanowali czas, miejsca, inne osoby, mieli szacunek dla siebie i własnego ciała oraz duszy, z respektem odnosili się do przeszłości, z zaufaniem spoglądali w przyszłość. Cenili moc błogosławieństwa spływającego na ludzi, zwierzęta, rośliny, pola, sady, studnie, drogi, rzeczy. Życie ludzi na wsi znaczone było nieustannymi aktami błogosławieństwa. Przyzywano w ten sposób „pomocy Bożej i opieki" na każdą sytuację i okoliczność życia, również tę dramatyczną. Ten ideał życia wiejskiego - w zgodzie z Bogiem, w harmonii z przyrodą, w solidarności $\mathrm{z}$ innymi ludźmi znał E. Bojanowski i chciał go upowszechniać.

Kultywowanie ludowych zwyczajów i obrzędów, wolnych od zabobonów i wyzwolonych z magii wyznaczało drogę wychowania. Obrzędowość doroczna, związana z czynnościami spełnianymi na roli, pieśni i piosenki wykonywane $\mathrm{w}$ różnych okolicznościach przesiąknięte były motywami religijnymi. W powiastkach i poezji, w śpiewie - jak zauważał E. Bojanowski - „ukryta” była mądrość ludowa. Mądrość tę wyrażały zwyczaje i obyczaje ludowe, przekazywane z pokolenia na pokolenie ${ }^{19}$. Wiedza religijna ludu wiejskiego była nieustannie utrwalana, ugruntowywana zwyczajowo. Wiedza ta obejmowała życie świętych, w tym patronów Polski. E. Bojanowski wielokrotnie podkreślał, że to lud wiejski chroni, ochrania tradycję, o której stanowiły obyczaje. To zaangażowanie środowisk wiejskich w zachowanie dziedzictwa przodków wpisywało się w troskę o kulturą chrześcijańską narodu polskiego.

${ }_{18}$ Zob. E. Gigilewicz, M.L. Opiela (red.), Prace, szkice i notatki ..., t. 1, s. 849-852.

19 Zob. tamże, t.2, s. 155-412; 445-586. 
E. Bojanowski proponował, by w zainicjowanych przez siebie ochronkach podtrzymywana była pamięć o „obrządkach”"20. To pozwoliłoby dzieciom przyzwyczaić się do pielęgnowania tradycji i jej świętowania. Zalecał, by w każdej ochronce pielęgnowane były specyficzne dla niej zwyczaje, związane zarówno z porami roku, jak i z świętami religijnymi wpisanymi w doroczną obrzędowość. Przykładał wagę do środowiska, otoczenia przyrodniczego, w którym żyły dzieci. Odradzająca się wiosną przyroda dawała E. Bojanowskiemu „natchnienie” do wyrażania poglądów na temat naturalnych sił, pobudzających do rozwoju dzieci. Polecał, by w ogrodach przy ochronka uprawiana była różnorodna roślinność „krajowa” - polska. Do jej motywów bowiem nawiązywała polska poezja i powiastki, polskie pieśni i piosenki. Świat przyrody przypominał też o uroczystościach religijnych ${ }^{21}$.

E. Bojanowski podzielił wspomniane wyżej „obrządki” na: światowe (mają one charakter epiczny; są malownicze; ich spełnianie wymaga od uczestników wdziania odpowiedniego ubioru; nie mniej ważne są określone atrybuty tu zastosowane); pobożne (o charakterze lirycznym; w czasie ich spełniania „wykonywane" są pieśni; wiążą się one z modlitwą); domowe (dotyczące bezpośrednio codzienności; ważne są tu osobiste czyny, uczynki, działania; sakralizują, czyli uświęcają one sytuacje i chwile domowego życia; w nich ogniskuje się niejako cała rzeczywistość życia) ${ }^{22}$.

\section{Ludoznawcza misja ochronek}

E. Bojanowski otaczając troską lud wiejski zdawał sprawę z konsekwencji osobistych i społecznych powszechnego braku wykształcenia w tym środowisku. Było to przyczyną życia „w zacofaniu”, a nawet „w ciemnocie”. Proponując określone idee odwoływał się niejednokrotnie do swoich obserwacji i badań zaczerpniętych z życia. Wiedział, że lud wiejski potrzebuje nie tylko instytucji podnoszących poziom wiedzy, ale nade wszystko tych formujących jego charakter moralny. E. Bojanowski akcentował w życiu ludu wiejskiego znaczenie świadomości praw przynależnych każdemu człowiekowi oraz poczucie własnej wartości, ugruntowanej na bogactwie kultury religijnej i dawnych obyczajów.

Ochronki zakładane przez Edmunda Bojanowskiego były domami dla dzieci pozostających bez opieki, służącymi pomocą rodzicom zmuszonym do zarobkowania poza ich i dzieci miejscem zamieszkania. Miały stanowić „straż-

\footnotetext{
20 Zob. tamże, t. 2, s. 263-270.

${ }_{21}$ Zob. tamże, t. 2, s. 27-39.

22 Zob. tamże, t. 1, s. 398, 419; t. 2, s. 263, 278.
} 
nice" rodzinnej tradycji i narodowych obyczajów ${ }^{23}$. Przez tradycję rodzinną rozumiał Bojanowski zwyczaje ludowe, które miały być starannie pielęgnowane w ochronkach. Dzięki temu lud mógł czerpać przykłady do ukochania wszystkiego, co swojskie.

W Regule Zgromadzenia Sióstr Służebniczek Boga-Rodzicy-Dziewicy Niepokalanie Poczętej E. Bojanowski wskazywał: „Jako człowiek z młodu się bawi, potem się uczy, a potem pracuje do końca dni swoich i na ostatek rachuje się ze wszystkich spraw żywota swego, tak dzieci już w ochronie w każdym dniu, tygodniu i całym roku tym samym porządkiem te sprawy odbywać mają"24.

Rozwojowi dziecka, jego doskonaleniu, przyzwyczajeniu się do rytmu obowiązków, służyć miały odpowiednio zaplanowane w ochronkach poszczególne dni tygodnia. Na przykład: „W poniedziałek po niedzielnym spoczynku u rodziców - pisał E. Bojanowski - wracają dzieci jakoby z porankiem nowo zaczynającego się tygodnia. A jak każdy dzień zaczynają od zabaw, tak cały pierwszy dzień tygodnia [...] mają więcej na zabawach i wesołych piosnkach niż na nauce i robotach przepędzić. Tym sposobem $z$ wolności, jaką miały w niedzielę, nieznacznie przejdą do zatrudnień ochronkowych i zabawy zachęcą je do licznego zebrania się w ochronce. Tego też dnia mają być przyjmowane nowo przybywające dzieci, aby się na początku zabawami do ochronki przynęciły [...]”. Natomiast „W środę, która jest przeznaczona nabożeństwu za dusze zmarłych ustać mają piosenki wesołe, a zabawy tylko cichsze i krótsze odbywać się mają [...]. Latem, jeśli cmentarz jest na wsi, będą zaprowadzane na groby. Tam [...] mają naprawiać mogiłki [...] i na cmentarzu zmówią wieczorny paciorek i Anioł Pański za zmarłych”. „W sobotę jako dzień poświęcony Najświętszej Pannie mogą się dzieci znowu bawić wesoło. W czasie nauki będą czynione zapytania z tego wszystkiego, czego się uczyły w tygodniu, a nauka katechizmu będzie główną rzeczą. Pieśni będą śpiewane o Najświętszej Pannie" 25 .

Nauczanie w ochronkach prowadzone było zgodnie z rytmem pór roku. Powiązane było z rokiem liturgicznym. Na wiosnę od Zmartwychwstania Pańskiego do Zielonych Świątek dzieci przebywały wiele na świeżym powietrzu, gdzie bawiły się. Zwyczaje wprowadzone do ochronek przez Bojanowskiego miały uczyć dzieci czynnej miłości, ofiarności i pracowitości.

W systemie wychowawczym Bojanowskiego dużą rolę odgrywały - jak już wyżej wskazano - piosenki, zarówno religijne, jaki i świeckie, odnoszące się

\footnotetext{
${ }^{23}$ Zob. tamże, t. 1, s. 624-625.

${ }^{24}$ Reguła Zgromadzenia Sióstr Stużebniczek Boga-Rodzicy-Dziewicy Niepokalanie Poczętej, cz II. Reguły w szczególności, Poznań 1867, \$ 15.

${ }_{25}$ Tamże, $\$ 44$.
} 
również do obrzędowości. Czerpał je albo bezpośrednio od ludu, albo częściej - $\mathrm{z}$ wydanych drukiem zbiorów. Sam nawet taki zbiór wydał dla ochronek ${ }^{26}$.

Prekursor wychowania integralnego wiedział, że człowiek przychodzi na świat nieukształtowany. Wszystkie płaszczyzny jego życia wymagały wobec tego oddziaływań pedagogicznych. Miał świadomość, że zręby osobowości ludzkiej istoty kształtują się od najmłodszych lat, a więc w domu rodzinnym, by następnie determinować całe jej życie ${ }^{27}$.

W swej koncepcji wychowania w ochronkach E. Bojanowski postawił na integralne, całościowe wychowanie małego dziecka, na uwzględnienie w prowadzonym procesie pedagogicznym możliwości psychicznych, tempa rozwoju fizycznego i duchowego, poziomu inteligencji, zainteresowań, uzdolnień i charakteru małych podopiecznych. Błogosławiony Edmund zalecał, aby wychowanie w ochronkach wprowadziło dzieci w całość spraw życiowych, aby od dzieciństwa poznawały wszystkie problemy egzystencji ludzkiej. Na podstawie jego wskazań zostały opracowane teoretyczne podstawy integralnej pedagogiki przedszkol$n^{228}$ i praktyczna jej realizacja według programu wychowania przedszkolnego ${ }^{29}$.

\section{Konieczność badań pedagogiczno-etnologiczno-religijnych}

Teoria i pragmatyka pedagogiczna E. Bojanowskiego jest wyzwaniem dla współczesnej pedagogiki. W kontekście przeprowadzonej analizy stwierdzić należy, iż konieczne są dziś badania pedagogiczno-etnologiczne.

Według ks. Józefa Węcławika SVD: „Zwyczaje, obrzędy oraz wierzenia Adwentu i Bożego Narodzenia nie tworzą pustych schematów, lecz są nosicielami wartości religijnych oraz świeckich. Pobożność zawiera się w oprawie kulturowej charakterystycznej dla regionu. Ukazuje hierarchię wartości religijnych i znajduje wyraz w uświęcaniu czasu, osób, przestrzeni, przedmiotów i różnego rodzaju czynności [...]

Tradycyjne formy pracy (darcie pierza, tkanie na krosnach, wytwarzanie narzędzi rolniczych w zimowe wieczory), przygotowanie strojów kolędniczych, spędzanie wolnego czasu niosły w sobie wartości, które miały charakter wychowawczy, a przekazując tradycję utrzymywały hierarchię wartości [...] Wspólne

${ }^{26}$ Piosnki wiejskie dla ochronek, z Przygrywką T. Lenartowicza, Poznań 1862, ss. 176, 2 nlb. Dzieło to ukazało się Nakładem Księgarni J. K. Żupańskiego

27 Zob. E. Gigilewicz, M.L. Opiela (red.), Prace, szkice i notatki ..., t. 1, s. 235-236.

${ }_{28}$ Opiela M., Integralna pedagogika przedszkolna w systemie wychowania Edmunda Bojanowskiego, Lublin 2013.

${ }^{29}$ M. Opiela, M. Kaput, E. Piekarz, A. Kornobis, Z. Zymróz, S. Chudzik, Program wychowania przedszkolnego według koncepcji pedagogicznej bł. Edmunda Bojanowskiego, Dębica 2008; wyd. 2 poprawione, Dębica 2015. Wydawcą pracy jest Zgromadzenie SSł. BDNP. 
spędzanie czasu podczas pracy czy świętego czasu i przekazywanie nauczania katolickiego wzmacniało poczucie tożsamości religijnej oraz narodowej. Śpiewanie kolęd, pochody kolędnicze przekazywały kolejnym pokoleniom prawdę o Narodzeniu Pana, ale także ukazywały wartości rodzinne, rodzicielskie oraz kształtowały światopogląd wiejski. Wartość rodziny, miłość rodzicielska, szacunek dla osób starszych, stosunek do obcych (np. Żydów) oraz swoich ukazywały postawy, według których starano się postępować przez cały rok.

Postać św. Mikołaja miała charakter niezwykle wychowawczy. Święty przynosił dzieciom paczki, jako szczególny dar woli Bożej. Zwyczaj rozdawania paczek przez św. Mikołaja przyznaje w tym współdziałanie matkom, które przygotowywały paczki. Za dobre sprawowanie i postępki dzieci otrzymywały paczki oraz szczególne wyróżnienie. Za złe postępowanie dzieci karano rózgami, ale także duchowo Św. Mikołaj często prowadził lekcje w szkole czy lekcje religii. I uważany był za wysłańca Bożego, który ukazywał łaskę Bożą"30.

Ks. Czesław Krakowiak uważa natomiast, iż „W Kościele obok liturgii ważną rolę pełnią także różne formy kultu, które wyrastają z żywej wiary. Ze względu na język, znaki i symbole, modlitwy i pieśni, często bardziej zrozumiałe dla ludu niż oficjalna liturgia Kościoła, również oddają cześć Bogu i zbliżają ludzi do Niego. Miejscem sprawowania liturgii jest zwykle kościół, natomiast ludowe zwyczaje religijne są najczęściej związane z życiem rodziny i społeczności lokalnej. Dzięki temu pełnią również ważną funkcję integracyjną i wychowawczą oraz przyczyniają się do zachowania nie tylko zwyczajów religijnych, ale także tradycji rodzinnych i narodowych. Dzięki nim można także poznać teologię ludową świąt i okresów liturgicznych. W miejscach i czasach, kiedy wierni nie mieli możliwości uczestnictwa w liturgii Kościoła, np. z braku duszpasterzy, prześladowań za wiarę, pobożne praktyki ludowe w rodzinie skutecznie służyły zachowaniu i przekazowi wiary chrześcijańskiej następnym pokoleniom. W naturalnych formach pobożności ludowej orędzie chrześcijańskie przyjmuje sposoby wyrazu danej kultury ale także ją chrystianizuje przez treści ewangeliczne"31.

„Pobożność ludowa - stwierdza ks. Jan Perszon - uczy dzieci i młodzież szacunku dla lokalnej tradycji, budzi dumę z tego, co «nasze», swojskie, specyficzne i unikalne, kształtując w ten sposób podstawę do patriotyzmu. Nie ma miłości wielkiej Ojczyzny bez pietyzmu względem tej najmniejszej, rodzinnej, sąsiedzkiej i wiejskiej (miejskiej). Rytuały i wierzenia ludowe kształtują też świadomość historyczną młodego pokolenia, a więc rodzaj osadzenia w dziejach rodzinnych, zapobiegając kosmopolitycznemu wykorzenieniu i bezideowości - charakterystycznej dla «ludzi znikąd». Wiele zwyczajów i wierzeń uczy

${ }^{30}$ J. Węcławik, [Kultywowanie tradycyjnych form obrzędowych], w: E. Sakowicz, Aspekt wychowawczy zwyczajów i wierzeń ludowych, „Ateneum Kapłańskie” 155(2010), z. 2, s. 272-273.

${ }^{31}$ Cz. Krakowiak, [W Kościele obok liturgii ważna rolę petnia także różne formy kultu, które wyrastajaz ż̇ywej wiary], w: E. Sakowicz, Aspekt wychowawczy zwyczajów i wierzeń ludowych, s. 275. 
zaangażowania społecznego, odwagi publicznego wyznawania wiary, trudnej sztuki wyjścia $\mathrm{z}$ «prywatnej» religijności ku tak dziś potrzebnemu w Kościele otwartemu świadectwu. Sprawowane społecznie rytuały (zwłaszcza nabożeństwa wiejskie, np. majowe, modlitwy o urodzaje czy przy zmarłych) są niezastąpioną szkołą solidarności międzyludzkiej, wspierania tych, którzy są w jakiejś biedzie czy niedoli. Ludowa pobożność - $\mathrm{w}$ dobie dominacji techniki nad człowiekiem - przywraca sakralny wymiar ludzkiej pracy i kształtuje umiejętność prawdziwego, tj. religijnego świętowania. Ponieważ większość zwyczajów, rytuałów i obrzędów dokonuje się w rodzinie, ludowa pobożność wzmacnia «rodzinność» chrześcijaństwa, akcentując teologiczny wymiar Kościoła domowego"32.

Powyższe wypowiedzi wybitnych badaczy ludowej teologii i pobożności oraz liturgiki wskazują na konieczność podjęcia i prowadzenie badań pedagogiczno-etnologiczno-religijnych. Za prekursora tych badań można uznać E. Bojanowskiego.

\section{Podsumowanie}

Edmund Bojanowski podkreślał znaczenie integralnego wychowaniu dziecka, które obejmuje sfery rozwoju jego osoby: fizyczną, umysłową, społeczną, kulturową, moralną, duchową (religijną). Wychowanie wraz z opieką i kształceniem staje się edukacją. Widząc dynamizm dziecka, pedagog ten zwracał uwagę na konieczność uwzględnienia „uposażenia” dziecięcej natury, by następnie w sposób przemyślany, logiczny ów plan procesu wychowania realizować. Chciał w ten sposób „ochronić” dziecko nie tylko przed wielorakimi, różnorodnymi niebezpieczeństwami, ale także - wychowując integralnie - w ogóle je „ochronić” przed złem i jednocześnie otworzyć na dobro, na Boga. W opracowanym przez siebie systemie pedagogicznym akcentował znaczenie wierzeń, zwyczajów oraz obrzędów. Zaznajamianie dzieci z nimi przyczynić się miało do ukształtowania w nich ducha patriotyzmu. Miało zakorzenić w tradycji, pielęgnowanej przez wieki przez przodków. E. Bojanowski wiedział, iż wierność imperatywom tradycji jest warunkiem sine qua non przyszłości, przyszłości wyrosłej na glebie tożsamości narodowej.

„Wizja” pedagogiczna bł. Edmunda Bojanowskiego mimo upływu blisko 150 lat od jego śmierci - nie straciła aktualności. Co więcej, na nowo odczytywana i analizowana staje się coraz bardziej wyrazista. Beatyfikowany w 1999 r. przez św. Jana Pawła II może być dziś patronem oświaty, edukacji i wychowania

32 J. Perszon, [Pobożność ludowa uczy dzieci i młodzież], w: E. Sakowicz, Aspekt wychowawczy zwyczajów i wierzeń ludowych, s. 276. 
w Polsce. Może patronować przedszkolom - personelowi i dzieciom oraz innym instytucjom wychowawczym.

Dzięki przykładowi E. Bojanowskiego, który „widział” wychowawcze znaczenie zwyczajów, wierzeń i obrzędów ludowych (i doceniał je, chociaż też „walczył” z zabobonami) mogą zostać zainicjowane i prowadzone badania pedagogiczno-etnologiczno-religijne. Pedagogiczny wymiar polskiej ludowej teologii i pobożności jest zatem wyzwaniem dla współczesnej pedagogiki.

\section{Biblografia}

Bartnik Cz. S., Mistyka wsi. Z autobiografii młodości, (wyd. 4), Radom 2003.

Gigilewicz E., Opiela M.L., Prace, szkice i notatki Edmunda Bojanowskiego. Inedita, t. 1-2, Lublin 2016. Kupisiński Z., Fenomen polskiej religijności ludowej, „Ateneum Kapłańskie” 155(2010), z. 2, s. 216-227. Kupisiński Z. (red.), Potrzeba religii. Dynamika praktyk religijnych i rytualnych, Lublin 2015.

Łobodziński J., Bogactwo ludowej teologii i pobożności, „Ateneum Kapłańskie” 155(2010), z. 1, s. 7-12. Marszałek L., Duchowość dziecka. Znacznie, perspektyw, konteksty w pedagogice przedszkolnej, Warszawa 2013.

Opiela M., Integralna pedagogika przedszkolna w systemie wychowania Edmunda Bojanowskiego, Lublin 2013.

Opiela M.L. (red.), Kompendium edukacyjne Edmunda Bojanowskiego, Lublin 2016.

Opiela M., Kaput M., Piekarz E., Kornobis A., Zymróz Z., Chudzik S., Program wychowania przedszkolnego według koncepcji pedagogicznej bł. Edmunda Bojanowskiego, Dębica 2008; wyd. 2 poprawione, Dębica 2015.

Perszon J., Pobożność ludowa - zmierzch czy transformacja?, „Ateneum Kapłańskie” 155(2010), z. 2, s. 228-246.

Reguła Zgromadzenia Sióstr Służebniczek Boga-Rodzicy-Dziewicy Niepokalanie Poczętej, Poznań 1867.

Sakowicz E., Aspekt wychowawczy zwyczajów i wierzeń ludowych, „Ateneum Kapłańskie” 155(2010), z. 2, s. 266-277.

Sakowicz E., Sens cierpień narodowych, "Cywilizacja. O Nauce, Moralności, Sztuce i Religii” 14(2006), s. 61-66.

Sakowicz E., Wychowanie do polskości, w: K. Kohler i in., Literatura, kultura religijna polskość. Księga jubileuszowa dedykowana prof. dr ha. Krzysztofowi Dybciakowi w 65. rocznicę urodzin, Warszawa 2015, s. 565-573.

\section{Streszczenie}

Edmund Bojanowski wpisał się na trwałe nie tylko w dzieje XIX w. Kościoła katolickiego w Polsce, ale i w rzeczywistość współczesną. Pozostawił po sobie bogate materiały archiwalne, pozwalające poznać horyzonty i głębię jego myśli, odkryć oryginalność i aktualność (wtedy i dziś) jego planów i zamiarów, w których centrum zawsze usytuowany był drugi człowiek, najbardziej zaś dziecko. Opracował koncepcję pedagogiczną, kładąc nacisk na podstawy teoretyczne, praktyczne i organizacyjne tzw. ochron - przedszkoli, będących miejscami pracy nad wszechstronnym - integralnym rozwojem dzieci. To właśnie ze względu na tę instytucję założył Zgromadzenie Sióstr Służebniczek.

Dorobek pisarski E. Bojanowskiego stanowią rękopisy, notatki z publikacji (książek, artykułów) innych autorów, zarówno jemu współczesnych oraz wcześniejszych. Wytrwały w poszukiwaniach, niestrudzony w sporządzaniu wypisów $\mathrm{z}$ lektur, gromadził materiały z wielu dziedzin nauki oraz 
kultury, w tym z zakresu folklorystyki i historii. W zbiorze archiwalnym znajdują się „dokumenty” mówiące o religijności ludowej, szkice żywotów świętych, formuły oraz teksty modlitw będące przykładem ludowej religijności. Rejestrował opowiadania, legendy, pieśni, piosnki. Zasób źródłowy E. Bojanowskiego ma wysoki walor poznawczy, rzec można - historyczny. Poprzez pracę dokumentalisty, pisarza służył on dziedzictwu kulturowemu Polski, będącej w jego czasach pod zaborami. Był heroldem suwerenności ojczyzny poprzez dzieło edukacji i wychowania dzieci.

Ludowa teologia, którą E. Bojanowski znał bardzo dobrze oraz pobożność ludowa, którą praktykował była dlań nie tylko „miejscem teologicznym”, ale równocześnie swoistą przestrzenią wychowywania dzieci i w ogóle młodego pokolenia. Pedagogiczny wymiar polskiej ludowej teologii i pobożności uwyraźniał się w systemie wychowawczym opracowanym przez błogosławionego pedagoga. Oryginalność i specyfika ludowej teologii i pobożności była wyzwaniem dla E. Bojanowskiego i złożonego przez niego zgromadzenia zakonnego. Siostry Służebniczki wpajały dzieciom patriotyczny „ducha”, inspirowanego właśnie przez polską ludową teologię i pobożność. Wychowywały do polskości. Edukacja służyć miała zachowaniu języka i dziedzictwa kultury, a tym samym tożsamości narodowej. Ostatecznie zaś miała przyczynić się do odzyskaniu przez Polskę niepodległości,.

Wierzenia, obrzędy i zwyczaje ludowe ujawniały szereg wychowawczych aspektów. Edmundowe ochronki pełniły ludoznawczą misję. Pozwalały odkryć, pielęgnować i utrwalać to, co było cenne właśnie w ludowej teologii i pobożności. E. Bojanowski akcentował w życiu ludu wiejskiego poczucie własnej wartości, posadowionej i ugruntowanej na bogactwie kultury religijnej i dawnych obyczajów. Ochronki miały być „strażnicami” rodzinnej tradycji i narodowych obyczajów.

Teoria i pragmatyka pedagogiczna E. Bojanowskiego stanowi wyzwanie dla współczesnej pedagogiki. Prowadzenie badań pedagogiczno-etnologiczne-religijnych jest dziś nakazem chwili.

Słowa kluczowe: Edmund Bojanowski, Siostry Służebniczki, ochronki, ludowa teologia, ludowa pobożność, wychowanie, edukacja.

\section{The pedagogical dimension of Polish folk theology and piety according to Edmund Bojanowski. An outline of pedagogical, ethnological and religious studies}

\section{Abstract}

Edmund Bojanowski became an integral part not only of the nineteenth-century history of the Catholic Church in Poland but also of contemporary reality. He left behind a rich archive of work that reflects his broad horizons and the depth of his thought, the originality and relevance (also today) of his plans and intentions that were always focused on the human being, particularly the child. He developed his pedagogical ideas, placing emphasis on the theoretical, practical and organisational foundations of the orphanages-kindergartens serving the integral development of children. This is why he established the congregation of the Sisters Servants of Mary Immaculate.

Bojanowski's output consists of manuscripts, notes to publications (books and articles) by other authors both contemporary to him and earlier ones. Persistent in his search, tireless in preparing extracts of what he read, he collected materials pertaining to many different fields of science and culture, including folklore studies and history. The archival collections comprise "documents" about folk religious customs, draft hagiographies, formulas and texts of prayers exemplifying folk religiousness. He recorded accounts, legends, songs. Bojanowski's own works and the materials he collected or documented are extremely valuable sources of knowledge and an important contribution to Poland's cultural heritage in the times when Poland was not an independent country. He was the harbinger of national sovereignty to be attained through the education and upbringing of children. 
The folk theology that Bojanowski knew very well and the folk piety that he practiced were not only a "theological space" to him but also a special space for bringing up children and educating youth. The pedagogical dimension of Polish folk theology and piety was manifested in the educational system developed by Bojanowski. The originality and uniqueness of folk theology and piety were a challenge to Bojanowski and the congregation he established. The children under the care of the Sisters Servants were brought up in the "patriotic spirit" inspired by Polish folk theology and piety. The goal of education was to preserve the language, cultural heritage and, consequently, the national identity. Ultimately, education was to help in the regaining of independence for Poland.

There was a number of educational aspects of folk beliefs, ritual and customs. Bojanowski's orphanages also serve an ethnological purpose, uncovering, fostering and preserving everything that was precious in the folk theology and piety. Looking at the life of the common people, Bojanowski emphasised their self-confidence rooted in the richness of religious culture and ancient customs. The orphanages were designed to be guardians of family traditions and national customs.

Bojanowski's pedagogical theory and pragmatics are a challenge to modern pedagogy. Taking actions at the intersection of pedagogy, ethnology and religion is imperative today.

Keywords: Edmund Bojanowski, Sisters Servants of Mary Immaculate, orphanages, folk theology, folk piety, upbringing, education. 